\title{
Penanganan Tindak Pidana Yang Dikualifikasi Delik Aduan
}

\author{
Julianus Edwin Latupeirissa ${ }^{1} \mathrm{Jacob}_{\mathrm{Hattu}}{ }^{2}$ Elias Zadrach Leasa ${ }^{3}$ \\ Program Studi Ilmu Hukum, Universitas Pattimura Ambon ${ }^{123}$ \\ Emai: nusyelatu@yahoo.co.id
}

\begin{abstract}
ABSTRAK
Laporan dan aduan merupakan hal yang berbeda, dalam Kitab Undang-undang Hukum Pidana ada delik biasa dan delik aduan, delik biasa dapat dilaporkan oleh semua orang namun dalam delik aduan tidak dapat diadukan semua orang, dalam perkara pidana Nomor 6/Pid.B/2018/PN.Drh yang disidangkan pada Pengadilan Negeri Dataran Hunipopu Seram Bagian Barat, saudara HW didakwakan Pasal 310 ayat (1) Kitab Undang-undang Hukum Pidana atas adulan yang dilakukan oleh AA. Tujuan penulisan ini untuk mengetahui apa akibat hukum jika penaganan delik aduan dengan aduan yang tidak sah, metode yang digunakan adalah metode penelitan hukum yuridis normatif, hasil dari pembahasan diketahui saudara saksi AA tidak mengadukan langsung perbuatan $H W$ namun lewat pengacara, namun dalam aduan tersebut pengacara tidak mencantumkan surat kuasa dari AA, tentunya surat kuasa tersebut cacat, dan fakta persidangan tidak ada dasar aduan yaitu surat kuasa dari korban kepada pengacara, akibat hukumnya adalah hakim menolak tuntutan jaksa (neit ontvankelijk verklaring van het OM) atau $H W$ Alias $H$ untuk dapat dituntut pidana seharusnya gugur atau putusan lepas dari tuntutan hukum (ontslag van rechtsvervolging) hal ini dapat dilihat dalam Pasal 319 Kitab Undang-Undang Hukum Pidana. Kesimpulannya dalam tindak pidana yang dikualifikasinya delik aduan, wajib ada aduan jika tidak ada maka tuntutan jaksa ditolak atau putusan pengadilan lepas dari tuntutan hukum.
\end{abstract}

Kata kunci: Penanganan, Delik, Aduan.

\section{Pendahuluan}

Kitab Undang-undang Hukum Pidana membagi beberapa jenis delik diantara ada jenis delik biasa atau gewone delic dan delik aduan atau klack delic, untuk jenis delik biasa tidak perlu adanya aduan dari korban untuk diproses hukum, sedangan delik aduan wajib mempunyai aduan tentang suatu perbuatan yang membuat korban merasa bahwa dia dihina. Dalam Bab XVI KUHP tentang penghinaan atau defamation atau bleeding. Ada lima perbuatan 
yang diklasifikasikan sevafau penghinaan yaitu :

$\begin{aligned} \text { Pertama : } & \text { BAB XVI KUHP } \\ & \text { tentang menista } \\ & \text { atau smaad. } \\ & \text { Menista ini dibagi } \\ & \text { menjadi menista } \\ & \text { secara lisan dan } \\ & \text { menista secara } \\ & \text { tulisan. Contoh, A } \\ & \text { menyiarkan berita } \\ & \text { bahwa B telah } \\ & \text { hamil di padahal } \\ & \text { tidak demikian, A } \\ & \text { dapat dikatakan } \\ & \text { menista; }\end{aligned}$

Kedua : Laster atau

memfitnah.

Contohnya C

mengatakan bahwa

D adalah seorang

koruptor,

kenyataannya tidak

ada putusan

pengadilan yang

telah secara sah

dan menyakinkan

serta telah

mempunyai

kekuatan hukum tetap bahwa D

telah melakukan

korupsi.

Ketiga : Penghinaan ringan atau eebvoudige belediging. Syarat seseorang

dikatakan

melakukan

penghinaan ringan, jika penghinaan terbut didegar langsung oleh orang yang dihina atau penghinaan tersebut dilakukan di depan umum, meskipun orang yang dihina tidak mendengarkan secara langsung misal : $\mathrm{X}$ menghujat $\mathrm{Y}$ mengatakan, "Y kamu mirip Anjing”. Jika ucapan yang berupa hinaan tersebut didengar langsung oleh $\mathrm{Y}$ dan tidak terima 


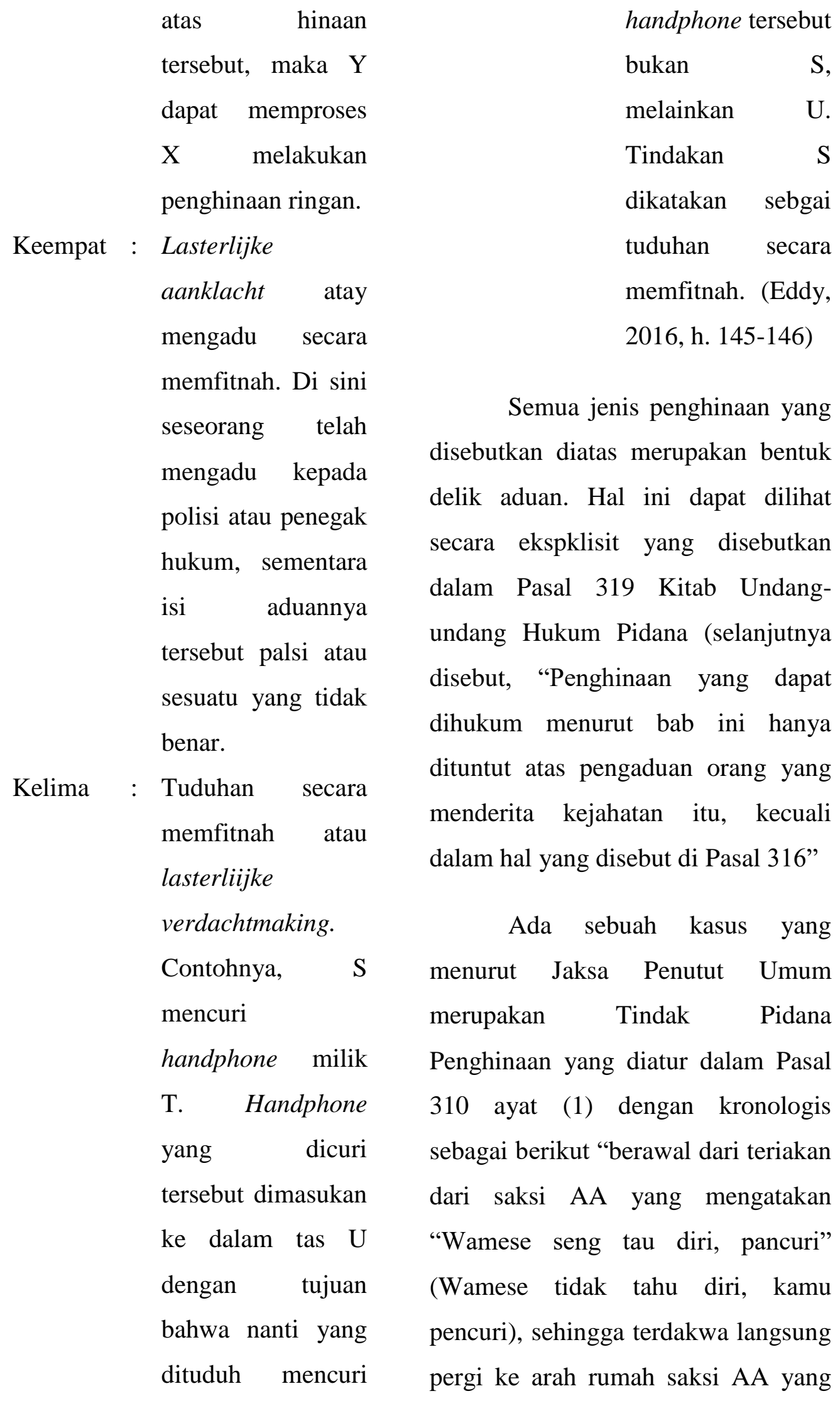


mana rumah terdakwa dengan saksi AA bersampingan. Setelah sampai di jalan yang berada di depan rumah saksi AA, kemudian terdakwa berteriak sambil berkata "kenapa seng berani keluar, ose lancang itu par sapa disini (kenapa kamu tidak berani kelur rumah, kamu lancang mulut)". Kemudian setelah terdakwa berkata hal tersebut, saksi AA keluar dari rumahnya dan terdakwa memasuki halaman rumah dari saksi AA. Pada saat terdakwa berada di halaman rumah saksi AA, kemudian terdakwa berkata sambil berteriak kepada saksi AA "sekolah tu cukup, kalau seng buta huruf nau-nau (Sekolah itu harus sampai tamat, sehinga tidak buta huruf, kamu bodoh), A besar seng tau (sesuatu yang semua orang tau, kamu tidak tau)", selanjutnya terdakwa menepuk dada sambil berkata "hey beta ni sarjana (saya ini sarjana), beta mama ni Bu Guru (ibu saya guru)", kemudian terdakwa melanjutkan perkataannya "kumang baru mendapat (kamu baru kaget memiliki suatu barang), su pernah cuci beta pung daki-daki (sudah pernah cuci saya punya kotoran), neniari ni bukan se kampong (Desa Neniari ini bukan kamu punya kampong), se pung lancang taruh akang di hutumury (kamu punya lancang mulut itu di Desa Hutumury jangan di Desa Neniari), tamaso dalam banyak hal (mencampuri banyak hal), lia tu badan su malele danose laki pancuri (lihat kamu sudah kehilangan berat badan karena suamimu pencuri), galojo (rakus), dan korupsi (kamu punya suami adalah pencuri, rakus dan korupsi).

Yang mengadukan perkara ini ke pihak Kepolisian Resort Seram Barat bukan Korban AA tetapi kuasa hukumnya berdasarkan Surat dari Kantor Advokat/Pengacara dan Konsultan Hukum Laturake \& Rekan, dengan nomor : 033/KAPKHLR/LP.I/VII/2018, Perihal : Laporan/Pengaduan, tertanggal 06 Juli 2018. Dari kronologis perbuatan diatas diketahui bahwa Terdakwa diduga telah melakukan penghinaan ringan sesuai tututan Jaksa Penuntut umum dalam perkara No. 6/Pid.B/2018/PN.Drh yang di sidangkan pada Pengadilan Negeri Dataran Hunipopu.

\section{Rumusan Masalah.}


Bahwa Pasal 310 KUHP ayat

(1) yang didakwakan terhadap terdakwa merupakan pasal yang termasuk dalam jenis delik aduan atau klack delic bukan jenis delik biasa atau gewone delic semua Pasal merupakan jenis delik aduan harus ada pengaduan yang dilakukan oleh korban, bukan dari orang yang bukan merupakan korban, dalam penulisan ini akan dibahas mengenai kasus di atas, yang tidak ada pengaduan dari korban.

\section{Metode Penelitian}

\section{A. Jenis Penelitian}

Mengingat penulisan ini merupakan penelitian hukum, maka metode yang digunakan adalah metode penelitian hukum. Penelitian hukum merupakan proses untuk menemukan aturan hukum, prinsipprinsip hukum maupun doktrindoktrin hukum untuk menjawab issue hukum yang dihadapi. Penelitian ini terutama mengkaji ketentuanketentuan hukum positif maupun asas-asas hukum yang bertujuan untuk pembaharuan hukum untuk mencari pemecahan masalah atas issue hukum sehingga hasil yang akan dicapai kemudian adalah memberikan preskripsi mengenai apa yang seyogyanya atas issue hukum yang diajukan. (Peter, 2008, h. 35)

Sesuai dengan permasalahan dan tujuan penelitian dari penelitian ini maka tipe penelitian yang akan digunakan dalah tipe penelitian yuridis normatif yakni suatu penelitian yang mengkaji ketentuanketentuan hukum positif, asas-asas hukum, prinsip-prinsip hukum maupun, doktrin hukum guna menjawab issue hukum yang dihadapi.(Peter, 2008, h. 36)

\section{B. Pendekatan Masalah}

Pendekatan yang digunakan dalam penelitian ini adalah pendekatan perundang - undangan (Statute approach), pendekatan konseptual (Conceptual approach), Pendekatan Kasus (Case Approach). Diharapkan dengan pendekatanpendekatan ini dapat menjawab permasalahan yang dihadapi. Selanjutnya pendekatan-pendekatan yang dipilih akan lebih memudahkan penulis untuk memberikan 
kesimpulan-kesimpulan dan saran saran bagi hasil.

\section{Sumber Bahan Hukum}

Baha-bahan hukum yang digunakan dalam penelitian ini terdiri dari :

a. Bahan hukum primer yaitu bahan-bahan hukum yang mengikat secara langsung, adalah bahan hukum berupa peraturan perundangundangan, yang terdiri dari

1. Undang-Undang Dasar Negara Republik Indonesia Tahun 1945

2. Kitab Undang-Undang Hukum Pidana

b. Bahan hukum sekunder yaitu yang memberi Penjelasan mengenai bahan hukum primer seperti berbagai bahan kepustakaan berupa buku, majalah, hasil penelitian, makalah dalam seminar, dan jurnal yang berkaitan dengan penelitian ini.

c. Bahan hukum Tersier Yaitu Bahan yang memberikan petunjuk maupun penjelasan terhadap bahan hukum primer dan sekunder yang mana terdiri dari:

1. Kamus hukum

2. Artikel artikel dan laporan dari media massa (surat kabar), jurnal hukum, majalah dan website dan lain sebagainya ).

\section{Teknik Pengumpulan Dan Analisis Bahan Hukum}

\section{D.1 Teknik Pengumpulan}

\section{Bahan Hukum}

Kegiatan pengumpulan bahan hukum dalam penelitian ini, penulis tempuh dengan melakukan library research. Penelitian ini dilakukan untuk memperoleh bahan hukum primer, bahan hukum sekunder, maupun bahan hukum tersier, bahkan ketiga bahan hukum tersebut dapat diperoleh melalui studi kepustakaan maupun juga dari media elektronik seperti internet, setelah semua bahan hukum dikumpulkan, kemudian akan diidentifikasi dan dijadikan sebagai bahan 
analisis terkait dengan permasalahan yang sudah dirumuskan sehingga dapat memperoleh jawaban dan solusi yang tepat terhadap permasalahan tersebut. mengenai data yang telah dikumpulkan melalui penelitian sekaligus memberikan makna, selain itu juga hasil tersebut diuraikan atau dipaparkan secara sistematis dan logis untuk menuju pada penarikan kesimpulan secara khusus.

\section{D.2 Teknik Analisis Bahan}

\section{Hukum}

Bahan hukum primer, bahan hukum sekunder dan bahan hukum tertier setelah dikumpulkan dan disusun secara sistematis, kemudian diklasifikasi dan dianalisis dengan cara menghubungkan satu teori dengan teori yang lain atau menghubungkannya dengan peraturan perundangundangan yang berlaku. Untuk menjawab permasalahan yang ada, maka bahan hukum yang dikumpulkan dianalisis secara kualitatif. Selanjutnya hasil tersebut diuraikan atau dipaparkan secara deskriptif aanalitis yaitu teknik analisis yang memberikan gambaran yang sejelas-jelasnya

\section{Hasil dan Pembahasan}

Bahwa ia Terdakwa $\mathrm{H}$ W Alias $\mathrm{H}$ pada tempus senin tanggal 11 Juni 2018 sekitar pukul 10.15, atau setidaktidaknya pada suatu waktu dalam bulan Juni 2018, locus di halaman rumah saksi AA di Desa Neniari Kec. Seram Barat Kabupaten Seram Bagian Barat. terdakwa dengan sengaja ,menyerang kehormatan atau nama baik seseorang dengan menuduhkan sesuatu hal yang maksudnya terang supaya hal itu diketahui umum, bentuk perbuatan terdakwa adalah berawal dari teriakan dari saksi AA yang mengatakan 
"Wamese seng tau diri, pancuri” (Wamese tidak tahu diri, kamu pencuri), sehingga terdakwa langsung pergi ke arah rumah saksi AA yang mana rumah terdakwa dengan saksi AA bersampingan. Setelah sampai di jalan yang berada di depan rumah saksi AA, kemudian terdakwa berteriak sambil berkata "kenapa seng berani keluar, ose lancang itu par sapa disini (kenapa kamu tidak berani kelur rumah, kamu lancang mulut)". Kemudian setelah terdakwa berkata hal tersebut, saksi AA keluar dari rumahnya dan terdakwa memasuki halaman rumah dari saksi AA. Pada saat terdakwa berada di halaman rumah saksi AA, kemudian terdakwa berkata sambil berteriak kepada saksi AA "sekolah tu cukup, kalau seng buta huruf nau-nau (Sekolah itu harus sampai tamat, sehinga tidak buta huruf, kamu bodoh), A besar seng tau (sesuatu yang semua orang tau, kamu tidak tau)", selanjutnya terdakwa menepuk dada sambil berkata "hey beta ni sarjana (saya ini sarjana), beta mama ni $\mathrm{Bu}$ Guru (ibu saya guru)", kemudian terdakwa melanjutkan perkataannya "kumang baru mendapat (kamu baru kaget memiliki suatu barang), su pernah cuci beta pung daki-daki (sudah pernah cuci saya punya kotoran), neniari ni bukan se kampong (Desa Neniari ini bukan kamu punya kampong), se pung lancang taruh akang di hutumury (kamu punya lancang mulut itu di Desa Hutumury jangan di Desa Neniari), tamaso dalam banyak hal (mencampuri banyak hal), lia tu badan su malele danose laki pancuri (lihat kamu sudah kehilangan berat badan karena suamimu pencuri), galojo (rakus), dan korupsi (kamu punya suami adalah pencuri, rakus dan korupsi). 


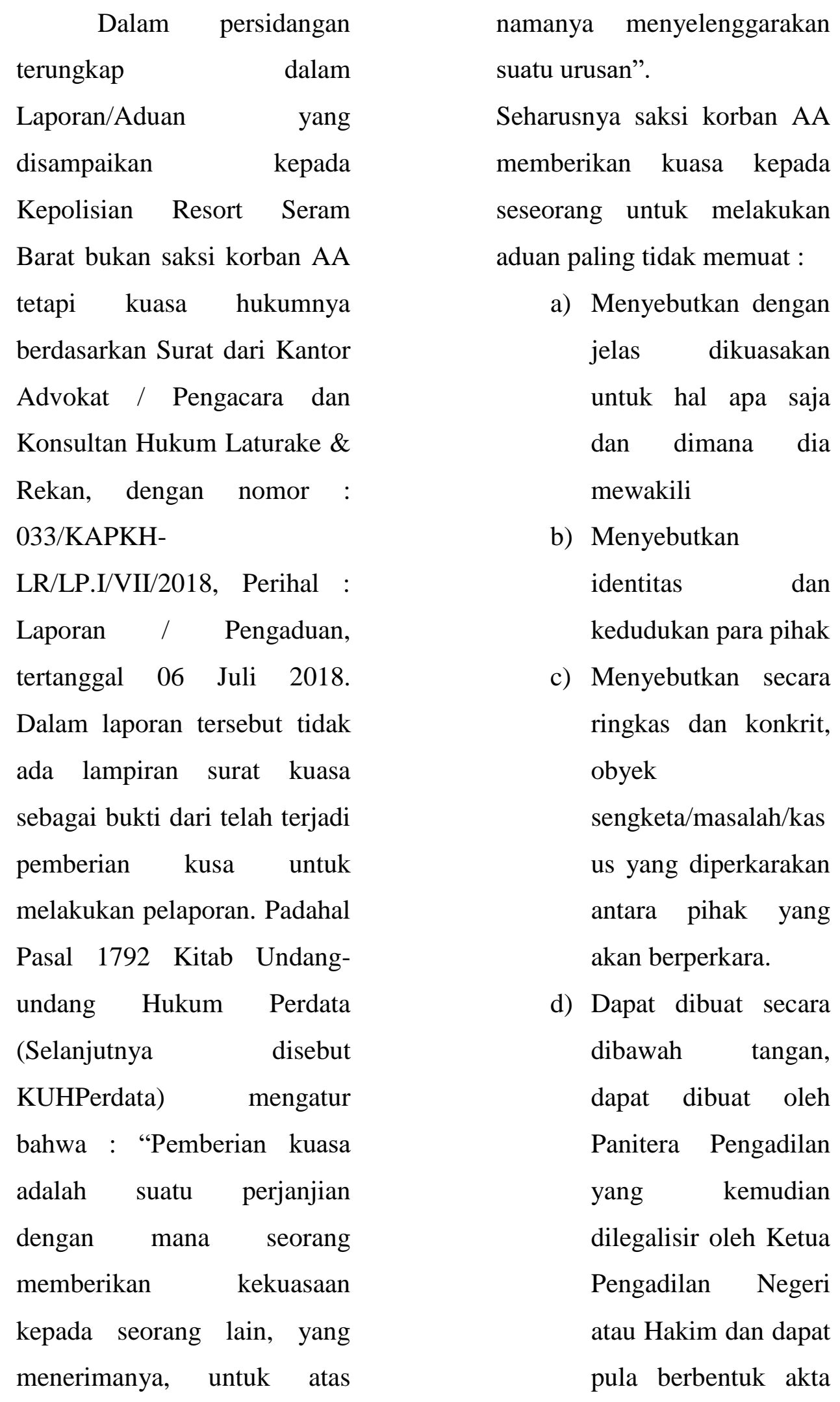


autentik yang dibuat dihadapan Notaris;

Akibat hukum dari tidak ada syarat diatas maka surat kuasa tersebut dinyatakan tidak sah, orang atau badan hukum yang mewakili pemberi kuasa yang tidak ada kuasanya, tidakannya tidak sah, untuk itu perlu adanya surat kuasa yang harus diberikan saksi korban AA kepada Pegacara yang mewakilinya melakukan pelaporan.

Salah satu diketahui telah terjadi suatu perbuatan pidana atau tindak pidana (strafbaar feit) salah satunya adalah aduan (vide Pasal 1 butir 25 KUHAP). Dalam KUHP ada beberapa delik aduan contohnya Pasal 284 KUHP (mukah), 287 KUHP (bersetubuh dengan perempuan dibawah umum), 293 KUHP (membujuk anak dibawah umur untuk berbuat cabul), 310-321 KUHP (penginaan), semua Pasal ini harus ada aduan. Kenapa harus ada aduan kerena saksi korban akan menjelaskan kerugian yang timbul karena perbuatan terdakwa contoh Pasal 310 ayat (1) Pasal 310 ayat (1) KUHP berbunyi :

Barangsiapa dengan sengaja menyerang kehormatan atau nama baik seseorang dengan menuduhkan sesuatu perbuatan, yang maksudnya terang supaya hal itu diketahui umum, diancam karena pencemaran dengan pidana penjara paling lama sembilan bulan atau pidana denda paling banyak $R p$ 4.500 ,-

Bahwa dari rumusan tersebut maka unsur-unsur yang dikandung dialam Pasal 310 ayat (1) KUH-Pidana yaitu

1. Unsur Barang Siapa;

2. Unsur Dengan Sengaja Menyerang Kehormatan atau Nama Baik Seseorang Dengan Menuduhkan Sesuatu Perbuatan;

3. Unsur Yang Maksudnya Terang Supaya Hal Itu Diketahui Umum.

Saksi korban harus mengadukan untuk menjelaskan 
unsur "dengan sengaja menyerang kehormatan atau nama baik seseorang dengan menuduhkan sesuatu perbuatan". Kehormatan atau nama baik apa yang saksi korban rasa telah diserang oleh terdakwa dan apa bentuknya serangan tersebut.

Pada Pasal 74 ayat (1) KUHP menyatakan bahwa Pengaduan hanya boleh diajukan dalam waktu enam bulan sejak orang yang berhak mengadu mengetahui adanya kejahatan, jika bertempat tinggal di Indonesia, atau dalam waktu sembilan bulan jika bertempat tinggal di luar Indonesia. Dalam hal kejahatan aduan, pengaduan itu menjadi syarat mutlak untuk dapatnya Negara (in casu Jaksa Penuntut Umum) melakukan penuntuatn pidana, kecuali dalam hal penghinaan terhadap pejabat (pegawai negeri) pada waktu atau karena menjalankan tugasnya yang sah (316 jo 319 KUHP). Peranan korban pada kejahatan aduan adalah menentukan untuk dapat tidaknya dilakukan penuntutan pidana (vervolging). (Chazawi 2007 h.201)
Fakta dalam persidangan tidak ada surat kuasa untuk pengaduan yang dilakukan kuasa hukum akibatnya tidak adanya aduan, dalam Putusan Pengadilan Negeri Dataran Hunipopu Nomor 6/Pid.B/2018/PN Drh, halaman 20 majelis hakim mempertimbangkan masalah tidak adanya aduan dalam berkas perkara pemeriksaan pada tingkat Kepolisian dan berkas perkara ketika sampai pada tahap penuntutan tidak ada pengaduan yang dilakukan oleh saksi korban, majelis hakim berpendapat bahwa masalah tersebut merupakan rana pemeriksaan pada tingkat pra peradilan, tentang sah tidaknya seseorang ditetapkan sebagai tersangka atas dasar laporan atau aduan dengan bukti awal yang cukup, menurut penulis Ratio decidendi dari majelis hakim adalah keliru, karena dalam Bab XVI Penghinaan, Pasal 319 menyebutkan "Penghinaan yang diancam dengan pidana menurut bab ini, tidak dituntut jika tidak ada pengaduan dari orang yang terkena kejahatan itu, kecuali berdasarkan Pasal 316". Pasal 319 jelas menentukan bagaimana penanganan Bab XVI tentang Penghinaan. Aduan 
adalah Wajib, ada pengecualiannya yaitu Pasal 316.

Menurut penulis pengaduan yang dilakukan oleh pengacara AA adalah tidak sah, maka dasar untuk terdakwa H W Alias H untuk dapat dituntut pidana seharusnya gugur atau putusan lepas dari tuntutan hukum (ontslag van rechtsvervolging) karena dasar pelaporan aduan tidak sah sehingga perbuatan terdakwa bukah tindak pidana seperti yang didakwakan oleh jaksa, dan jika dalam pembacaan sidang pembuktian tidak ada lampiran pengaduan oleh saksi korban dalam berita acara pemeriksaan maka hakim dapat menolak tuntutan jaksa (neit ontvankelijk verklaring van het $O M$ ) vide Pasal 319 KUHP. (Hamzah, 2011 h.125)

\section{Penutup}

\section{Kesimpulan}

\section{Perkara Nomor}

6/Pid.B/2018/PN.Drh dengan terdakwa $\mathrm{H}$ W alias $\mathrm{H}$, dan saksi korban AA, terdakwa didakwakan dengan Pasal 310 ayat (1) KUHP. AA melakukan pengaduan pada pihak Kepolisian Resort Seram Barat, namun tidak mengadukan langsung ke Polres namun diwakilkan oleh Pengacara, namun dalam aduan tersebut tidak ada surat kuasa oleh AA, dalam persidangan terungkap bahwa surat kuasa tidak perna ada dalam berita acara persidangan. Hal ini menimbulkan kecacatan karena tidak terbukti dilakukan pengaduan, Pasal 310 ayat (1) KUHP merupakan jenis delik aduan, aduan merupakan unsur absolut dari Pasal tersebut.

\section{Saran}

Tuntutan atas Perkara Nomor : 6/Pid.B/2018/PN.Drh, karena tidak sahnya aduan karena tidak ada surat kuasa atas aduan saksi korban AA maka seharusnya majelis hakim dapat menolak tuntutan jaksa (neit ontvankelijk verklaring van het $O M$ ) atau menyatakan terdakwa $\mathrm{H}$ W Alias $\mathrm{H}$ untuk dapat dituntut pidana seharusnya gugur atau putusan lepas dari tuntutan hukum (ontslag van rechtsvervolging) karena dasar pelaporan aduan tidak sah. 


\section{Daftar Pustaka}

Chazawi, A. (2007). Pelajaran Hukum Pidana, Dasar Peniadaan, Permberatan dan Peringanan, Kejahatan Aduan,Perbarengan dan Ajaran Kausalitas. Jakarta: PT Raja Grafindo Persada.

Eddy, S. O. Hiariej. (2016). Prinsip-Prinsip Hukum Pidana. Yogyakarta: Cahaya Atma Pustaka.

Hamzah, A. (2011). Hukum Acara Pidana Indonesia. Jakarta: Sinar Grafika.

Mahmud, P. M. (2008). Penelitian Hukum. Jakarta: Kencana.

Soesilo, R. (2007). Kitab Undang-undang Hukum Pidana (Serta Komentarkomentarnya). Bogor: Politea. 